\title{
Facing the Consequences of Sexual Abuse in the Daily Life of the Survivors ${ }^{*}$
}

\section{The significance of the family and sexual abuse}

The identity of the individual is built in relation to others, starting in the family. In the family, the child will, for the first time, hear the answer to the question of who and what he is, and will start to create the first image of himself, on which he will only continue building throughout life. Even if a child grows up in a safe environment and later experiences a traumatic experience of sexual abuse, this can drastically affect his self-image. ${ }^{1}$ But, if a child is abused within the family, he will experience, even more intensely, that something is wrong with him, that he is strange, dirty, and abominable, because he has been abused instead of loved. Since his self-esteem is so low, he will later most likely find it more difficult to trust others, he will retreat to his own private world, or he will always be available for exploitation and

\footnotetext{
* The author acknowledges the partial financial support from the Slovenian Research Agency (project No. J5-9349).

1 J. S. Scharff, D. E. Scharff, New Paradigms for Treating Relationships, New York 2006, Jason Aronson.
} 
abuse, which, by all means, confirms his low self-esteem and negative selfimage. ${ }^{2}$

On the other hand, it is considered that the family environment, which has provided security from the beginning, is the one that will help the abused to recover from trauma faster and will provide more support; consequently, in cases where the family environment is very unhealthy, it will be harder to support the individual, and makes it more difficult to be compassionate during the process of overcoming the distress he will experience. Research ${ }^{3}$ shows that family support and the appropriate reaction at the disclosure of abuse help the abused to recover sooner and to experience less traumatic consequences. Thus, his self-image and body were less affected by abuse than in the case where his family members did not believe him or the act of sexual abuse was minimized. ${ }^{4}$

\section{Sexual abuse and self-image}

If a child grows up in a family that does not provide security and is permeated by violence, abuse, neglect, etc., the child receives messages that the world is dangerous, too, that one has first to take care of others, that it is not appropriate to have one's own needs, let alone to speak about them; such a child experiences enormous fears, distress and pain, which intensifies the development of a negative self-image. ${ }^{5}$

Research shows that there is a positive correlation between a history of sexual abuse and negative self-image. A sexually abused person begins to perceive herself as disgusting, ugly, inadequate, different and stigmatized both emotionally and physically ${ }^{6}$. The affects left by the act of sexual abuse

\footnotetext{
2 T. Repič Slavič, Nemi kriki spolne zlorabe in novo upanje [Silent screams of sexual abuse and a new hope], Celje: Celjska Mohorjeva družba 2015, Društvo Mohorjeva družba.

3 D. R. Catherall, Handbook of stress, trauma, and the family, New York 2004, Brunner-Routledge.

4 H. Y. Swanston, A. M. Plunkett, B. I. O’Toole, S. Shrimpton, P. N. Parkinson, R. Oates, Nine years after child sexual abuse, "Child Abuse \& Neglect" 27 (2003) 8, pp. 967-84.

5 B. Corby, Childabuse towards a knowledge base, 2006, Open University Press. Norton.

C. Courtois, Healing the incest wound: Adult survivors in therapy, New York 1988,
} 
are so deeply engrained that they change the victim's psychic structure. ${ }^{7}$ She begins to doubt whether she is still normal, she perceives herself as weird, hypersensitive, etc.

To sum up the findings from clinical work ${ }^{8}$ with the sexually abused, the following picture emerges:

- They compare themselves to others and perceive themselves as inferior and less successful. In particular, women often say that they do not feel pretty or attractive and that it is more secure for them to suppress their female nature. For them it feels too vulnerable, too dangerous to be gentle, mild, to allow themselves to feel fragile and sensitive. Simultaneously, they intensely desire and yearn for these exact attributes.

- They wish they had more self-esteem, determination, self-confidence and were less dependent on others.

- They experience a lot of fears, especially the fear of refusal, the fear to risk something new and make changes, of being alone, of being genuine and show others what they really feel, what they really are; they fear every imaginable illness, exposure, etc.

- They often experience feelings of guilt, shame, unwantedness, and a negative opinion about themselves.

- Sometimes they perceive themselves as being a small and helpless child, naïve, frightened, incapable of living alone and in this regard immature.

- They tend to blame themselves, they experience ambivalence and extreme emotional fluctuations.

- Frequent excessive control of their feelings or the other extreme - no control at all.

A negative opinion about oneself, frequent experiences of emotional extremes, and in particular fears - all these serve primarily as a defense of the psyche against pain. ${ }^{9}$ Since one's self-perception is partly connected with

7 T. Repič Slavič, C. Gostečnik, Relational family therapy as an aid toward resolving the trauma of sexual abuse in childhood in the process of separation in the couple relationship, "Journal of Marital and Family Therapy" 43 (2017) 3, pp. 422-434.

8 T. Repič Slavič, Nemi kriki spolne zlorabe in novo upanje [Silent screams of sexual abuse and a new hope], Celje: Celjska Mohorjeva družba 2015, Društvo Mohorjeva družba.

9 C. Gostečnik, Relacijska paradigma in travma [Relational paradigm and trauma], Ljubljana 2009, Brat Frančišek in Frančiškanski družinski inštitut. 
the relation to one's own body, the next chapter will examine more closely where and how sexual abuse can be linked to an individual's body.

\section{Sexual abuse and the body}

The body remembers everything. Each touch, each sensation, body position, affect, etc., all is recorded in the physical, somatic memory. Children begin to discover themselves and the world around them through their bodies. With sexual abuse the message that is engrained in their psyche and body is that the world is not a safe place, that adults are not trustworthy, that the body is something dirty and ugly, etc. Abuse penetrates so deeply that it can powerfully impact how the victim eats, breathes, feels, and, above all, how she will relate to her body. ${ }^{10}$ When an abused person experiences the world as a dangerous place, he adapts to this in various ways, in order to survive in the body with all distress and pain. He will dissociate from the body ("It seems to me that I'm not in my body", etc.), he will experience a split ("I feel that I float above my body and observe it from the ceiling"), numbness, addictions, and self-destructive behavior. ${ }^{11}$

\subsection{Sexual abuse and psychosomatic health issues}

A traumatic experience affects not only the structure and functioning of the brain, but also the stability of the psyche, thoughts and physical health. In extreme cases, trauma can also contribute to a significant amount of psychiatric disorders. ${ }^{12}$ In many cases, medical examinations and tests do not explain the symptoms of a patient who has been traumatized. This does not mean that the patient does not suffer from physical pain, but that the cause of the pain is psychosomatic. It is recognized that most of these patients are demanding, frightened, insecure, and sometimes do not even trust their loved ones who assure them that definitely everything is all right with them. Many suffer from a variety of medical symptoms, most often

\footnotetext{
10 C. Gostečnik, T. Repič Slavič, T. Pate, R. Cvetek, Body language in relational family therapy, "Journal of Religion and Health" 57 (2018) 4, pp. 1538-1553.

11 B. Rotschild, The body remembers: The psychophysiology of trauma and trauma treatment, New York 2000, W. W. Norton \& Company.

12 S. Knauer, Recovering from sexual abuse, addictions, and compulsive behaviors: "Numb" survivors, New York NY 2002, Haworth Press.
} 
due to indigestion, chronic fatigue, and sleep disorders. Scaer ${ }^{13}$, who has worked as a medical doctor for many years and has treated various patients, among them those suffering an accident or some other trauma, believes that various physical syndromes (pains) in traumatized cases are more often the result of an experience itself than of proven body injuries. "For example: Stomach ache is caused by psychological distress experienced by the sexually abused, not by an organic condition or food poisoning." Similarly, the trauma of sexual abuse can affect neurological and hormonal (endocrine) changes, the immune system etc. The emotional state of a person affects her physical well-being and health. An increasing number of authors emphasize the connection between mind, brain and body. The brain functions and responds on the basis of the stimuli that they receive from the surroundings and from the body. They compare current experiences with the past ones. The body responds to brain orders and changes according to the stimuli and messages it receives from the brain. According to all stored memories, the mind directs the behavior of the body and influences the contents of the memories that will be stored in the future.

From the above findings, we can see that the atmosphere and the emotional and physical states during trauma are very strongly linked to the functioning of the brain, which further affects physical changes, including illnesses and health.

Generally, healthcare and medicinal research ${ }^{14}$ shows that individuals who were sexually abused in the past have more health problems and report more somatic symptoms and aches than those who were not victims of sexual abuse. They also report more chronic illnesses. The most common and most general are: gastro-intestinal diseases, stomach disorders (ulcer), respiratory disorders (e.g. asthma, bronchitis, emphysema - over-inflation in the lungs), heart problems, hypertension, arthritis, diabetes, and gynecological problems in women. Gynecological problems are most often associated with the loss of menstrual cycle or excessive bleeding, sexual dysfunction, frequent lower abdominal pain (even when the woman does not menstruate), frequent inflammation of the sexual organs and pain during sexual intercourse.

13 S. Robert, The trauma spectrum: Hidden wounds and human resiliency, New York, NY 2005, W. W. Norton \& Company.

14 A. Schore, Affect regulation and the origin of the self: The neurobiology of emotional development, New York 2016, Taylor \& Frances/Routledge. 
Golding et al. ${ }^{15}$ interviewed women seeking help due to serious premenstrual problems (PMS); they found that $95 \%$ of these women reported that at least once they experienced an attempt of sexual abuse, or were actually sexually abused, while $81 \%$ of these women were raped.

Some authors ${ }^{16}$ also report chronic inflammation of the bladder, frequent and painful urination, which increases with women during their period. According to research, $90 \%$ of women with a history of sexual abuse have these problems.

The health problems mentioned above can be a valid reason why sexually abused women are more likely to use pills and other medical devices.

In addition, the trauma of sexual abuse can have a direct impact on the health of the person abused, as during the abuse itself victims may be exposed to infection or even become infected with a sexually transmitted disease. Abuse can also indirectly harm the health of the victim, as it increases the likelihood that the abused person will become entangled in abusive relationships. In this respect, relational family theory speaks of the unconscious attraction of abuse or loyalty to feelings associated with abuse (disgust, shame, contempt, fear, etc.). The psyche unconsciously seeks this atmosphere, with the hope that these affects will be resolved in order for something new, something non-abusive to happen. Research shows that the individuals who were raped are much more prone to physical violence in an intimate couple relationship, compared to those who do not have a history of rape ${ }^{17}$. And physical violence, of course, increases the likelihood of serious injuries to at least one of the partners.

Clinical experience and research ${ }^{18}$ show that the sexually abused can quickly begin to perceive their body as dysfunctional, which is closely linked to psychosomatics. Some become preoccupied with each physical change, and at the slightest sign of illness they experience real horror as if they were very seriously ill. The impact of this psychological distress and perception are reflected in many physical, organic manifestations; in other words, psychic

15 C. S. Rodgers, J. L. Ariel, E. W. Twamley, M. B. Stein, Sexual trauma and pregnancy: A conceptual framework, “Journal of Women's Health" 12 (2003) 10, pp. 961-970.

16 J. M. Golding, Sexual assault history and physical health in randomly selected Los Angeles women, "Health Psychology" 13 (1994) 2, pp. 130-138.

17 B. van der Kolk, The body keeps the score: Mind, brain and body in the transformation of trauma, New York 2014, Penguin Books.

18 C. M. Gilbert, Psychosomatic Symptoms: Implications for Child Sexual Abuse, "Journal of Mental Health Nursing" 9 (2009) 4, pp. 399-408. 
pain is transferred to the body and the body's message is that there is something it can no longer tolerate. All these physical signs are psychosomatic and can manifest in: headaches (only as tension or as migraine), sleep disorders, appetite disorders, stomach problems, gynecological problems (chroniclower abdominal pain, dyspareunia, vaginismus, non-specific vaginitis, menopausal disorders, etc.), asthmatic and cardiac problems, muscular tension, fainting, vertigo, fatigue, etc. The same authors explain psychosomatic problems as a result of sexual abuse with the help of a chronically stimulated autonomic nervous system, which increases the secretion of hormones (epinephrine, norepinephrine and cortisol). It is this constantly increased secretion that causes long-term harm to the body.

Sometimes, psychosomatic problems in a certain part of the body that was injured during abuse occur much later, even after several years, e.g. jaw pain if the person was raped orally. However, there may be problems that are more difficult to notice: lower physical immunity, susceptibility to colds and flu, chronic fatigue and exhaustion, etc. ${ }^{19}$

In addition to all these possible illnesses that may be associated with sexual abuse, it is necessary to emphasize that it is not necessary that each disease is a result of sexual abuse; but it can, of course, point out this possibility, especially if it is psychosomatic.

\subsection{Sexual abuse trauma and negative behaviors which affect health and relation to one's body}

Sexual abuse initially occurs on body level, which is why many sexually abused individuals accuse their body because it was responsive, attractive, small, vulnerable, and receptive to arousal and pleasure; they blame themselves to have physical sensations at all. Relaxation, therefore, may in some respects represent an unconscious risk that something bad will surely happen, and it is safer to be constantly alert and awake, since this child who was sexually abused could never truly relax. Likewise, many sexually abused individuals perceive their body as a burden, and they do not pay proper attention to it, because precisely when it should defend them, it escaped and betrayed them. This disregard for bodily needs involves not hearing

19 P. K. Trickett, J. G. Noll, E. J. Susman, C. E. Shenk, F. W. Putnam, Attenuation of cortisol across development for victims of sexual abuse, "Development \& Psychopathology" 22 (2010) 1, pp. 165-175. 
the body's messages: they work even when they are sick, they ignore the urge to urinate because they want to finish a task, they do not rest when it is high time to take a break, they go to extremes with eating or physical activities, are prone to self-injuries, develop various addictions, etc. All these extremes, which most often occur under severe stress, are the ways to escape, or in other words, the ways in which the abused want to calm their body and silence or at least reduce distress. As we will see, there are many ways of calming the body, but none provides a long-term solution to the problem because its roots are deeper.

\subsubsection{Sexual abuse and eating disorders}

Symbolically, food represents feelings. Through food, a person can control heavy and unchanging feelings, because this is the only way she can control her body: by symbolically controlling food. ${ }^{20}$ In this context, we will focus on the three most common eating disorders, which are more frequent among women than men: compulsive overeating (binge eating disorder), anorexia and bulimia.

Compulsive overeating: The causes of compulsive overeating may vary. Some individuals who have survived sexual abuse "stuff" themselves with food in order to reduce the feelings of pain, fear and emotional hunger. In other words, they escape to the world of comfort, but most often immediately after overeating, they feel even more disgusting and ugly, and literally hate themselves. Through food they try to satisfy other emotional needs, not hunger. They may yearn for acceptance, embrace, love, respect, but since this is unobtainable, food can bring at least momentary satisfaction. On the other hand, overeating can be a way to protect oneself - with excessive fat - from being abused again. Our society sends messages that overweight women are less sexually attractive and therefore less exposed to sexual initiatives and attacks. Although this is not true, many women really feel less vulnerable if they are overweight.

Anorexia: Similarly to compulsive overeating, anorexia means that a person is trying to protect herself and gain control over her life. When she tries to strictly control what enters her body and what does not, she tries to regain the power she was bereaved of during the abuse. The rejection of

20 J. S. Scharff, D. E. Scharff, New Paradigms for Treating Relationships, New York 2006, Jason Aronson. 
food also symbolizes the rejection of life and all distress and affects that an anorexic person can no longer let in, let alone emotionally process. Food equals affects. ${ }^{21}$ Many girls who have been sexually abused may have problems with anorexia in puberty because they are convinced that they will not be attractive unless their hips and breasts are developed enough, in short, if they are not women. They feel that being a woman is dangerous, because if such cruel things happen to children, as adults one can expect only worse. Or they come from families where the mother as a woman experienced a lot of violence and horror, and daughters then unconsciously do not want to become adults. Anorexic girls' families often seem as having very rigid, crystalized patterns, black and white beliefs (they only know what is right or wrong, there is nothing in between); the opinion and needs of only one family member (usually the father) count, while others' feelings are ignored. Symbolically, we can say that just as there is no room for food and compassion, there is no space for the feelings and needs of others. An anorexic girl cannot accept all these rude affects, so she resorts to obsessive rituals, often also taking great care of order and cleanliness. She rejects food, but at the same time becomes obsessed with her body that she cannot accept. Her distorted self-image is accompanied by perfectionism and preoccupation with food, weight, the collection of recipes and the study of calories and various diets for losing weight.

Bulimia: Vomiting is the body's way of symbolically saying "No". Through food the abused person controls what will enter her body, and if it is not digestible, it will quickly leave the body by vomiting or by taking laxatives. In this way, the individual "throws up" disgust, shame, fear, and similar distressful affects she is unable to regulate in other ways. For example, "if, as a child, she experienced the abuser pushing his penis, fingers or other objects into victim's body openings (mouth, vagina, and / or anus), causing choking or even vomiting, the survivor may now symbolically, through vomiting, unconsciously want to get all these out of their body. Or, on the contrary, she will experience real horror and panic at the slightest feelings of being sick, as this will awaken in the body a memory of abuse and thus all suppressed feelings will start to emerge." Bulimic girls often come from chaotic families, where there are no boundaries between the parents' and

21 E. Bass, L. Davis, The courage to heal: a guide for women survivors of child sexual abuse, New York 2008, Collins Living. 
children's subsystems. Everyone knows everything, and children do not feel safe. There are too many feelings that cannot be digested, therefore a bulimic person becomes the victim who finds comfort and calm in eating. Initially, food is a source of satisfaction, but soon the individual is faced with severe distress and crises because of excessive weight which she tries to get rid of in every possible way. For this purpose, she uses all imaginable means to help her evacuate all excess food (vomiting, enema, laxatives, fitness with impossibly demanding schedule, etc.). ${ }^{22}$

Another way of relaxing unprocessed distress through the body is through self-injury and / or addiction.

\subsubsection{Self-injury}

Self-injury includes all forms of harming oneself by causing physical injuries with various objects (cutting with knives, glass shards, razor blades; burning with cigarette, etc.). Some women who have experienced sexual abuse are struggling against its effects by abusing themselves. Because they have been sexually abused in childhood, they are used to torture and do not even know anything else. In this way, they try to control events, punish themselves, express anger towards themselves, and, last but not least, feel their body. Self-abuse is a way of re-creating the abusive situation and causes feelings that these individuals are well aware of. Often self-torture brings a strong sense of relief and relaxation of the tension that they yearn for. For example: "A woman had frequently severe attacks of horror and vaginal pain at night. When she could no longer withstand the pressure, she began to push various objects into her vagina so that she injured herself. Immediately afterwards she began to feel relief, she calmed down and fell asleep. This behavior may be difficult to understand and can cause disapproval, but it does have an explanation. When this woman was a child, she went to bed every evening horrified that her father would abuse her again at night. She was lying awake until he arrived - and tortured her by inserting objects into her vagina. She only fell asleep when he left because she knew that agony for that night was over." All of these acts in adulthood show some distress in the past, and often these individuals cannot even find an explanation for them. They may not even remember that they have been abused, but through their behavior all pains and horrors, which they have once experienced, are played out. Only

22 C. Gostečnik, Relational family therapy: the systemic, interpersonal, and intrapsychic experience, New York; London 2017, Abingdon: Routledge. 
linking past abuse and current actions can make a significant contribution to resolving abuse and changing such behavior. Most cases of self-mutilation are not noticeable at all, but they always mean a cry for help. In other cases, this can be the way to attract attention - to hurt themselves. It is always a source of strong feelings of shame, humiliation, and mortifying fear, which most victims are not aware of, but they are felt by others when they see a cut and injured body.

\subsubsection{Addictions}

Addiction is a way to escape, a search for relaxation, security, and control. It numbs pain and strong feelings, suppresses memories that the addict cannot accept, and it can be one way to survive with the effects of trauma - including sexual abuse. There is increasing evidence that the victims of sexual abuse are more likely to resort to behaviors that have a negative impact on their health than those who have not experienced sexual abuse trauma. One of these behaviors is the use of substances such as tobacco, alcohol, and other drugs. Various studies have shown that traumatized women are more prone to smoking, they start to smoke earlier, and smoke more passionately and more frequently ${ }^{23}$. Women with a history of sexual abuse drink alcohol more often, they become more often involved in risky behaviors under the influence of alcohol (e.g. driving a car), while also reporting that they feel the need to reduce the use of alcohol.

In the context of addiction, Knauer uses the term "anesthesia" to describe the ways or means used by people who have survived sexual abuse to be able to function day by day with emotional, sometimes even physical pain. Some victims are externally highly functional and are excellent workers, responsible for a huge amount of tasks and assignments; we might even say that they are addicted to work, only to redirect and alleviate pain or even mere thinking about abuse. Others get depressed and are lethargic, without motivation and energy to do anything. They sleep all day, find comfort in food and begin to fail in all areas. Both groups need a lot of energy and power to hold back or conceal rage and the feeling of helplessness, which are, inter alia, the effects of sexual abuse. Knauer speaks of several types of anesthesia, but their common feature is that the victim, whenever she becomes involved in some behavior, is absorbed and driven by this anesthesia like a slave; we

23 C. Gostečnik, Relacijska paradigma in travma [Relational paradigm and trauma], Ljubljana 2009, Brat Frančišek in Frančiškanski družinski inštitut. 
could even say that she is in a state that is very similar to trance achieved by hypnosis. Different individuals resort to different behaviors to ease the pain of abuse. The purpose of anesthesia is to redirect, to distract attention, the focus of the pain of sexual abuse. One of the most commonly used anesthesia is alcohol, and adolescents often use drugs. Eating disorders are also closely related to sexual abuse. Young adolescents who have experienced sexual abuse more often become anorexic and bulimic, while older adolescents more often suffer from compulsive overeating or binge eating disorder. In addition to substance abuse, various compulsive behaviors may also occur that serve to reduce and mitigate emotional suffering caused by sexual abuse. Among the most common compulsive behaviors are: gambling, compulsive squandering money, compulsive television viewing or playing computer games, compulsive overeating, and many others. All such behaviors serve as an unconscious defense against the pain caused by sexual abuse. The victim feels that some compulsive behavior or substance abuse helps her to silence her pain or, at least for a few moments, to not feel distress, anxiety, fear, guilt, and all other feelings left by abuse. The ways in which victims dull the pain of abuse are as many as there are ways of abuse.

\section{Conclusion}

The messages sent to the victim by sexual abuse are very complex and harmful, as they have violated the most intimate personal boundaries. There is nothing more sacred than the body. To be sexually abused is a message to the victim that her body is not her property, that sexual services are the only valuable thing she can offer, and that what is felt by the victim is irrelevant to the torturer. It is no wonder that the victims resort to various compulsive behaviors, psychosomatic diseases and addictions, in order to stupefy and dull their pains. Clinical experience suggests that there are ways that can reduce distress associated with the effects of trauma. The first way is the family. If abuse does not occur within the family, and the individual is supported by family members, she will recover much sooner. In addition to the family, positive experiences in other relationships also play an important role, including a therapeutic relationship and the therapy itself. Last but not least, individuals in therapy report that their faith in Someone (God or a 
higher power) who is above them, helps them in the times of crises, when they feel utterly powerless, so that they feel more peaceful ${ }^{24}$. And if one feels peace inside, then for their happiness they will not need harmful behaviors, addictions, patterns, and relationships.

\section{Bibliography}

Bass E., Davis L., The courage to heal: a guide for women survivors of child sexual abuse, New York 2008, Collins Living.

Brener N. D., McMahon P. M., Warren C. W., Douglas K. A., Forced sexual intercourse and associated health-risk behaviors among female college students in the United States, "Journal of Consulting and Clinical Psychology" 67 (1999) 2, pp. 252-259.

Bung-Nyun K., Park S., Min-Hyeon P., The Relationship of Sexual Abuse with Self-Esteem, Depression, and Problematic Internet Use in Korean Adolescents, "Psychiatry Investigation" 14 (2017) 3, pp. 372-375.

Catherall D. R., Handbook of stress, trauma, and the family, New York 2004, Brunner-Routledge.

Corby B., Child abuse towards a knowledge base, 2006, Open University Press.

Courtois C., Healing the incest wound: Adult survivors in therapy, New York 1988, Norton.

Fonagy P., Gergely G., Jurist E. L., Target M., Affect regulation, mentalization, and the development of the self, New York, NY 2007, Other Press.

Gilbert C. M., Psychosomatic Symptoms: Implications for Child Sexual Abuse, "Journal of Mental Health Nursing" 9 (2009) 4, pp. 399-408.

Gostečnik C., Relacijska paradigma in travma [Relational paradigm and trauma], Ljubljana 2009, Brat Frančišek in Frančiškanski družinski inštitut.

Gostečnik C., Repič Slavič T., Pate T., Cvetek R., Body language in relational family therapy, "Journal of religion and health" 57 (2018) 4, pp. 1538-1553. Gostečnik C., Relacijska paradigma in klinična praksa [Relational paradigm and clinical practice], Ljubljana 2013, Brat Frančišek in Frančiškanski družinski inštitut.

24 B. Simonič, N. Rijavec Klobučar, Experiencing positive religious coping in the process of divorce: a qualitative study, "Journal of religion and health" 56 (2017) 5, pp. 1644-1654. 
Gostečnik C., Relational family therapy: the systemic, interpersonal, and intrapsychic experience, New York; London 2017, Abingdon: Routledge.

Knauer S., Recovering from sexual abuse, addictions, and compulsive behaviors: "Numb" survivors, New York NY 2002, Haworth Press.

Repič Slavič T., Nemikrikispolnezlorabe in novo upanje [Silent screams of sexual abuse and a new hope], Celje: Celjska Mohorjeva družba 2015, Društvo Mohorjeva družba.

Repič Slavič T., Gostečnik C., Relational family therapy as an aid toward resolving the trauma of sexual abuse in childhood in the process of separation in the couple relationship, "Journal of Marital and Family Therapy" 43 (2017) 3, pp. 422-434.

Robert S., The trauma spectrum: Hidden wounds and human resiliency, New York, NY 2005, W. W. Norton \& Company.

Rodgers C. S., Ariel J. L., Twamley E. W., Stein M. B., Sexual trauma and pregnancy: A conceptual framework, "Journal of Women's Health" 12 (2003) 10, pp. 961-970.

Rothschild B., The body remembers: The psychophysiology of trauma and trauma treatment, New York 2000, W. W. Norton \& Company.

Scarf, M., Secrets, lies, betrayals: How the body holds the secrets of a life and how to unlock them, New York 2004, Random House.

Scharff J. S., Scharff D. E., New Paradigms for Treating Relationships, New York 2006, Jason Aronson.

Schore A., Affect regulation and the origin of the self: The neurobiology of emotional development, New York 2016, Taylor \& Frances/Routledge.

Swanston H. Y., Plunkett A. M., O’Toole B. I., Shrimpton S., Parkinson P. N., Oates R., Nine years after child sexual abuse, "Child Abuse \& Neglect" 27 (2003) 8, pp. 967-84.

Trickett P. K., Noll J. G., Susman E. J., Shenk C. E., Putnam F. W., Attenuation of cortisol across development for victims of sexual abuse, "Development \& Psychopathology" 22 (2010) 1, pp. 165-175.

van der Kolk B., The body keeps the score: Mind, brain and body in the transformation of trauma, New York 2014, Penguin Books.

Simonič B., Rijavec Klobučar N., Experiencing positive religious coping in the process of divorce: a qualitative study, "Journal of Religion and Health" 56 (2017) 5, pp. 1644-1654. 